\title{
Ergenlerde Siber Zorbalık ve Siber Mağduriyet ile İlişsili Değişkenlerin İncelenmesi
}

\author{
Cyber Bullying and Cyber Victimization in Adolescents
}

\begin{abstract}
Zahide DALMAÇ POLAT ${ }^{*}$ Seda BAYRAKTAR ${ }^{* *}$

Öz: Bu araştırmanın amacı, ergenlerde siber zorbalık ve siber mağduriyetle ile ilişkili olduğu düşünülen sosyo-demografik değişkenlerin (yaş, cinsiyet, okul, vb.), internet kullanımı ile ilişkili değişkenlerin, öfke ve öfke ifade tarzları, stres ile başa çıkma tarzları ve boyun eğme değişkenlerinin etkisini incelemektir. Çalışma, İstanbul ili Nesrin Uçmaklıoğlu Teknik Meslek Lisesi, Atatürk Endüstri Meslek Lisesi ve Güç Kardeşler Anadolu Lisesi kurumlarına devam eden 506 öğrenci üzerinde kolayda örnekleme yoluyla gerçekleştirilmiştir. Araştırma örneklemini 213 erkek (\%42.1) ve 293 (\%57.9) kız öğrenci oluşturmaktadır. Araştırma da Kişisel Bilgi Formu, Siber Zorbalık Ölçeği, Siber Mağduriyet Ölçeği, Sürekli ÖfkeÖfke İfade Tarzı Ölçeği, Stresle Başa Çıkma Tarzları Ölçeği ve Boyun Eğici Davranışlar ölçeği kullanılmıştır. Elde edilen bulgular kapsamında cinsiyete, öğrencinin kaçıncı sınıfta okuduğuna, babanın eğitim durumuna, bilgisayar oynama değişkenine göre siber zorbalık puanları açısından anlamlı bir fark vardır. Siber mağduriyet puanları açısından bakıldığında kaçıncı sınıfta okuduğuna, okul başarısına göre anlamlı bir fark bulunmaktadır. Boyun Eğici Davranış Ölçeği Puanı ile Siber Mağduriyet Ölçeği Puanı arasında istatistiksel olarak anlamlı ilişki bulunmamıştır, benzer şekilde Boyun Eğici Davranış Ölçeği Puanı ile Siber Zorbalık Ölçeği Puanı arasında da istatistiksel olarak anlamlı ilişki bulunmamıştır.
\end{abstract}

Anahtar sözcükler: Siber Zorbalık, Siber Mağduriyet, Stres, Öfke, Boyun Eğme

Abstract: The main purpose of this study was to examine the effects of socio-demographic variables (age, gender, school, etc.), internet usage related variables, anger and anger expression styles, submissive and coping styles concerning cyber bullying and cyber victimization amongst adolescents. Data was collected from 506 students at the Nesrin Uçmakoğlu Technical Vocational High School, Atatürk Industrial Vocational High School and Güç Kardeşler Anatolian School in Istanbul through the sampling method. The sample for this study comprised 213 male students (42.1\%) and 293 female students (57.9 \%). A Personal Information Form, Cyber Bullying Scale, Cyber Victimization scale, Submissive scale, Trait Anger, an Anger Expression scale and a Coping Styles inventory were employed. Depending upon the data concerning gender, student's grade, father's education status and playing video games variables, significant differences were found to occur in cyber bullying. From cyber victimization the student's grade and academic success have significant differences. A significant relationship was not found between the Submissive scale and Cyber Victimization scale and also the same pattern was observed between the Submissive Scale and Cyber Bullying Scale.

Keywords: Cyber Bullying, Cyber Victimization, Stress, Anger, Submissive.

\footnotetext{
* Uzman Psikolog, İstanbul. zahidedalmac@hotmail.com

** Yrd. Doç. Dr., Akdeniz Üniversitesi, Edebiyat Fakültesi, Psikoloji Bölümü, Antalya. sedabayraktar@akdeniz.edu.tr Bu makale Zahide Dalmaç’ın Haliç Üniversitesi Uygulamalı Psikoloji Yüksek Lisans Programı kapsamında yapmış olduğu tez çalışmasından oluşturulmuştur. I. Uluslararası Çocuk Koruma Kongresi’nde sözel bildiri olarak sunulmuş ve özet kitapçığında yer almıştır.
} 
Teknolojide yaşanan hızlı gelişmeler bilgi ve iletişim teknolojilerinin kullanımını hızlı bir şekilde yaygınlaştırmaktadır. Son yıllarda cep telefonu, bilgisayar ve internetin kullanımının artmasıyla birlikte yaşanılan çağ "teknoloji çă̆ı" olarak adlandırılmakta ve insanların birbiriyle olan iletişimi kolaylaşırken teknolojik aletlerin kullanımı da yaşamın vazgeçilmez bir parçası haline gelmektedir (Soydaş 2011; Özbay 2013).

Gelişen elektronik iletişim ağları, insan yaşamını kolaylaştırmasının yanı sıra yeni problemleri de beraberinde getirmektedir. Kuşkusuz bu teknolojik gelişmelerin eğitim ve öğretime sağladığı yararlar tartışılmaz düzeydedir. Bununla birlikte ortaya çıkan etik sorunlar ise madalyonun diğer yüzünü oluşturmaktadır. Klinik, eğitim, adli psikoloji gibi alanların gündeminden hiç düşmeyen, en popüler konuların başında zorbalık (bullying) gelmektedir. Teknolojideki gelişmeler ve teknolojinin gençler tarafından daha yaygın kullanılması bazı durumlarda gençlerin teknolojiyi kullanarak zorba davranışlarda bulunmaları ile sonuçlanabilmektedir. Bilgi ve iletişim teknolojilerinin kötü niyetli kullanımı okullarda öğrenciler arasında yaşanan zorbalık türleri arasında "siber zorbalık" (cyberbullying) adı verilen yeni bir zorbalık türünün gözlenmesine neden olmuştur. Siber zorbalık, bilgisayar, cep telefonu ve diğer iletişim teknolojileri aracılığıyla bir birey ya da gruba karşı yapılan kasıtlı ve tekrarlanan teknik ya da ilişkisel tarzda zarar verme davranışlarının tümüdür (Li 2006; Belsey 2007; Hinduja \& Patchin 2009; Tanr1kulu, Arıcak, \& Kınay 2011; Yaman, Eroğlu \& Peker 2011).

Gelişen yeni teknoloji okullarda internet ve cep telefonu gibi araçların kullanımını artırmış ancak bu durum beraberinde bu araçların problemli kullanımı ve başkalarıyla zararlı şekillerde tanışma ve etkileşime girme gibi sorunlara yol açmıştır. Bilgisayarların ve cep telefonların evde, okulda, sosyal mekanlarda kullanılması internetin gerçek dünyadaki gibi sosyal yaşam alanını sanal ortamda sunması; kişilerin dünyayı keşfetmeleri, öğrenmeleri ve eğlenmeleri için ortam sunarken; bir yandan da şiddet ve cinsellik içeren oyunlara erişimin ve pornografik görüntülerle karşılaşma olasılığının artması, cinsiyet ayrımcılığı ya da 1rkçılığı yücelten sitelere girilmesi, tehlikeli insanlarla iletişime geçmelerini kolaylaşmasıyla kişilere kişisel bilgilerin açıklanması ve bu kişilerle yüz yüze buluşulması çocuk ve gençler için büyük riskler taşımakla birlikte bağımlılığa da yol açabilmektedir. Bu durum kişilerin ruh hallerini, duygu durumlarını (öfke, hakaret, tehdit, taciz, zarar verme vb.) sanal ortama da aktarmasına yol açmaktadır (Sarak 2012; Özbay 2013).

Zorba davranışlar konusunda yapılan araştırmalara bakıldı̆̆ında araştırmacıların zorba davranışları farklı bakış açılarıyla tanımladıkları görülmektedir. Zorbalık, bazı araştırmacılar için bir çocuğun diğer çocuklar üzerindeki fiziksel ve psikolojik yollarla baskı kurması ve onları incitici davranışlarda bulunması iken bazı araştırmacılar bu tür davranışların zorbalık olarak kabul edilmesi için düzenli olarak tekrar edilmiş olması gerektiğini ifade etmektedir (Şahin, Sar1, Özer \& Er 2010; Manap 2012). Bilgi ve iletişim teknolojilerinin gelişimi ve bunun kötü amaçlı kullanımıyla birlikte araştırmacılar tarafından artık zorbalığın yeni bir formuyla, siber zorbalıkla ve beraberinde siber mağduriyetle karşı karşıya olduğumuz belirtilmektedir. Siber mağduriyet, bilgi ve iletişim teknolojileri aracılığıyla bir birey ya da grubun, özel ya da tüzel bir kişiliğin, teknik ya da ilişkisel tarzda zarar verici davranışlara maruz kalması ve bu davranışlardan maddi ya da manevi olarak mağduriyet yaşaması durumudur (Arıcak, Kınay \& Tanrıkulu 2012).

Siber zorbalık olumsuz anlamda fiziksel, bilişsel, duygusal ve sosyal sonuçlara varabilecek travmatik bir deneyim olarak tanımlanmaktadır (Patchin \& Hinduja 2006). Dolayısıyla bu travmatik deneyimin saldırganı ya da mağduru olmanın duygusal anlamda sebepleri ve sonuçları bulunmaktadır. Bu kapsamda siber zorbalık ve mağduriyette önemli olduğu düşünülen ve bu araştırmada yer verilen kavramlar şu şekilde ele alınmaktadır. Öfke, tutum ile davranışlar aracılığıyla toplumu rahatsız eden sosyal olumsuzluklar (Walker 2010); Stres, canlının fiziksel 
ve ruhsal sınırlarına karşı tehdit oluşması sonucu ortaya çıkan bir durum (Bayraktar 2012) ve boyun eğme, insanların yapmak istemedikleri halde kendilerinden istenileni yapmaları olarak tanımlanmaktadır (Freedman, Sears \& Carlsmith 1998).

Ergenlerde siber zorbalık ve siber mağduriyetle ile ilişkili değişkenlerin incelemesi amaçlanan bu araştırmada aşağıdaki sorulara cevap aranmıştır:

1. Ergenlerin sosyo-demografik ve internet kullanımına ilişkin değişkenler ile siber zorbalık-mağduriyet puanları arasında anlamlı bir farklılık var mıdır?

2. Ergenlerde boyun eğici davranış puanları ile siber zorbalık-mağduriyet puanları arasında ilişki var mıdır?

3. Ergenlerde sürekli öfke ve öfke ifade tarzları puanları ile siber zorbalıkmağduriyet puanları arasında ilişki var mıdır?

4. Ergenlerde stresle başa çıkma tarzları puanları ile siber zorbalık-mağduriyet puanları arasında ilişki var mıdır?

\section{Gereç ve Yöntem}

\section{Araştırmanın Modeli}

İlişkisel tarama modeli ile yapılan bu araştırma da, ergenlerin siber zorbalık ve mağduriyet değişkenlerine etkisi olduğu düşünülen sosyo-demografik değişkenler, internet kullanımı ile ilişkili değişkenler, öfke ve öfke ifade tarzları, stresle başa çıkma tarzları ve boyun eğici davranış değişkenlerine ilişkin veriler sistemli bir şekilde istatistiksel analize tabi tutulmuş, elde edilen veriler betimsel yöntemle açıklanmıştır

\section{Araştırmanın Evreni ve Örneklemi}

Araştırmanın evrenini 2013-2014 eğitim öğretim yılında İstanbul İli Milli Eğitim Bakanlığı'na bağlı devlet okullarda liseye $(9,10,11$ ve 12 'nci sınıf) devam eden öğrenciler oluşturmaktadır. Araştırmanın örneklemini kolayda örnekleme yöntemiyle seçilen 506 lise öğrencisi oluşturmaktadır.

Öğrencilerle ilgili diğer demografik verilere Tablo 1'de ve Tablo 2'de yer verilmiştir.

Tablo 1. Araştırmaya Katılan Bireylerin Çeşitli Değişkenlere İlişkin Dağılımı

\begin{tabular}{llll}
\hline & & $\boldsymbol{F}$ & $\boldsymbol{\%}$ \\
\hline \multirow{4}{*}{ Yaş } & 19 yaşında & 36 & 7.1 \\
& 18 yaşında & 71 & 14.0 \\
& 17 yaşında & 151 & 29.8 \\
\hline Cinsiyet & 16 yaşında & 137 & 27.1 \\
& 15 yaşında & 111 & 21.9 \\
\hline \multirow{4}{*}{ Okul } & K1z & 293 & 57.9 \\
& Erkek & 213 & 42.1 \\
\hline \multirow{3}{*}{ Sinıf } & Güç Kardeşler Anadolu Lisesi & 152 & 30.0 \\
& Atatürk Endüstri Meslek Lisesi & 155 & 30.6 \\
& Nesrin Uçmaklıŏlu Teknik Meslek & 199 & 39.3 \\
\hline & Lisesi & 138 & 27.3 \\
& 9. Sınıf & 147 & 29.1 \\
Annelerin eğitim düzeyi & 10. sınıf & 142 & 28.1 \\
& 11. sinıf & 79 & 15.6 \\
\hline
\end{tabular}




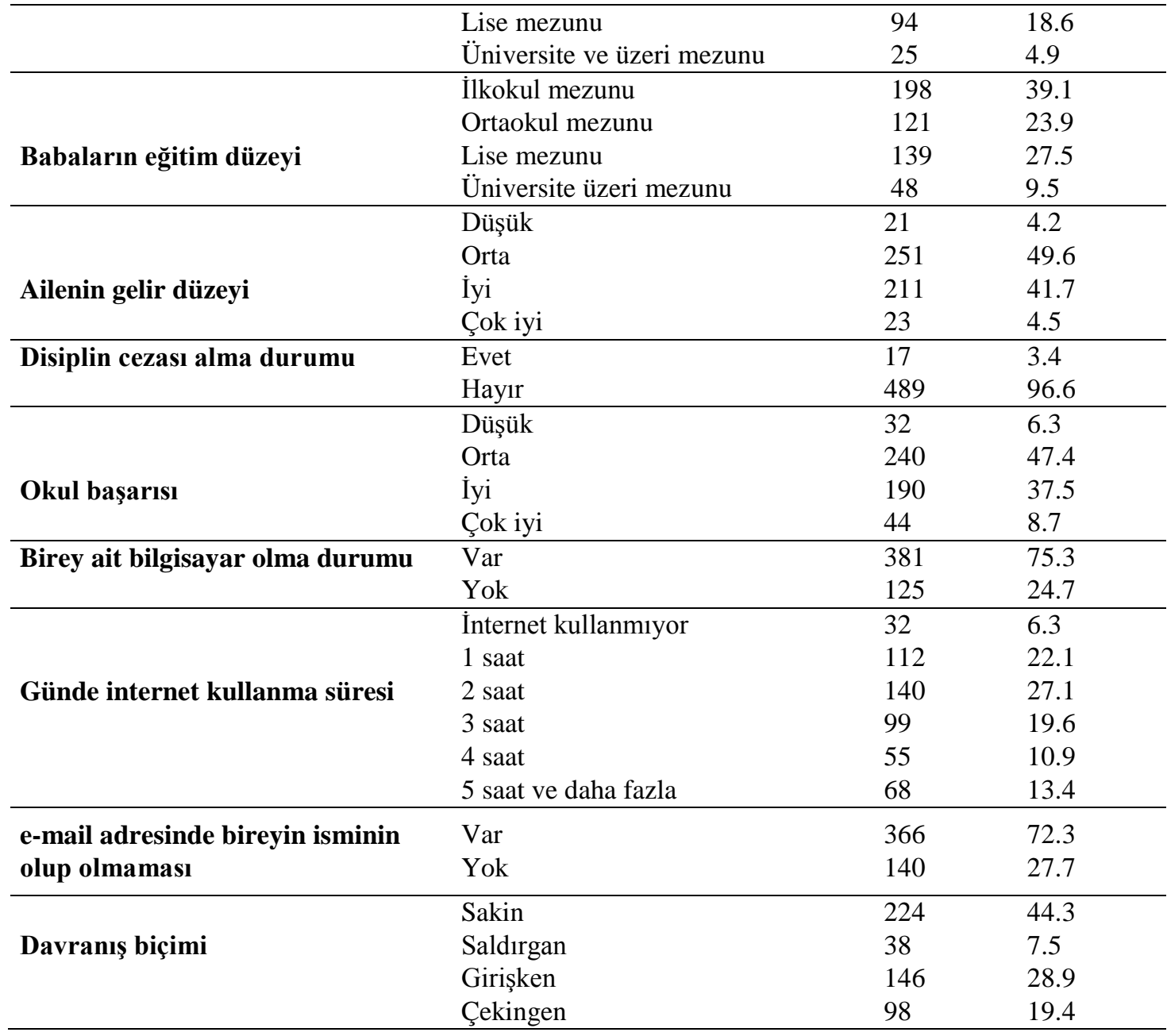

Tablo 1'de görüldüğü gibi araştırma dahilinde Kişisel Bilgi Formununu yanıtlayan 506 bireyin 293’ünü (\%57.9) kızlar ve 213’ünü (\%41.2) erkekler oluşturmaktadır. Bireylerin 151’i (\%29.8) 17 yaşında, 137'si (\%27.1) 16 yaşında, 111'i (\%21.9) 15 yaşında, 71’i (\%14,0) 18 yaşında ve 36’sı (\% 7.1) 15 yaşındadır.

Tablo 2. Araştırmaya Katılan Bireylerin İnterneti Ne Amaçla Kullandıkları ile Oynadıkları Bilgisayar Oyunlarına İlişsin Dağılımı

\begin{tabular}{llll}
\hline & & $\boldsymbol{F}$ & $\mathbf{\%}$ \\
\hline İnterneti ne amaçla kullandıkları & & & \\
\hline Sosyal paylaşım için internet kullanma & Hayır & 222 & 43.9 \\
& Evet & 284 & 56.1 \\
\hline Müzik dinleme için internet kullanma & Hayır & 262 & 51.8 \\
& Evet & 244 & 48.2 \\
\hline Eŭitim için internet kullanma & Hayır & 306 & 60.5 \\
& Evet & 200 & 39.5 \\
\hline Sohbet için internet kullanma & Hayır & 355 & 70.2 \\
& Evet & 151 & 29.8 \\
\hline Forum için internet kullanma & Hayır & 467 & 92.3 \\
& Evet & 39 & 7.7 \\
\hline \multirow{2}{*}{ Ĕglence için internet kullanma } & Hayır & 282 & 55.7 \\
\hline
\end{tabular}




\begin{tabular}{llll}
\hline & Evet & 224 & 44.3 \\
\hline Bilgisayar oyunu olarak ne oynadıkları & & & \\
\hline Zeka oyunları oynama & Hayır & 366 & 72.3 \\
& Evet & 140 & 27.7 \\
\hline Aksiyon oyunları oynama & Hayır & 375 & 74.1 \\
& Evet & 131 & 25.9 \\
\hline Strateji oyunları oynama & Hayır & 383 & 75.7 \\
& Evet & 123 & 24.3 \\
\hline Savaş oyunları oynanma & Hayır & 379 & 74.9 \\
& Evet & 127 & 25.1 \\
\hline Spor oyunları oynama & Hayır & 403 & 79.6 \\
& Evet & 103 & 20.4 \\
\hline
\end{tabular}

Bireylerin 284'ü (\%56.1) sosyal paylaşım siteleri için interneti kullanmaktadır. Bireylerin 244'ü (\%48.2) müzik dinlemek için interneti kullanmaktadır. Bireylerin 200'ü (\%39.5) eğitim için interneti kullanmaktadır. Bireylerin 151’i (\%29.8) sohbet etmek için interneti kullanmaktadır. Bireylerin 39’u (\%7.7) fromlar için internetti kullanmaktadır. Bireylerin 224'ü (\%44.3) eğlence için interneti kullanmaktadır. Bireylerin 366's1 (\%72.3) zeka oyunları oynamazken 140'1 (\%27.7) zeka oyunları oynamaktadır. Bireylerin 375'i (\%74.1) aksiyon oyunları oynamazken 131'i (\%25.9) aksiyon oyunları oynamaktadır. Bireylerin 383'ü (\%75.7) strateji oyunları oynamazken 123'ü (\%24.3) strateji oyunları oynamaktadır. Bireylerin 379'u (\%74.9) savaş oyunları oynamazken 127'si (\%25.1) savaş oyunları oynamaktadır. Bireylerin 403'ü (\%79.6) spor oyunları oynamazken 103 'ü (\%20.4) spor oyunları oynamaktadır.

\section{Veri Toplama Araçları}

\section{Kişisel Bilgi Formu}

Araştırmacı tarafından hazırlanan kişisel bilgi formunun ilk kısmında cinsiyet, sınıf, kardeş sayıs1, kardeş sırası, doğum tarihi, anne-baba eğitim durumu, gelir düzeyi gibi demografik özelliklere yer verilmiştir. İkinci kısımda sahip oldukları bilgisayar sayısı, internet kullanım amac1, günlük internet kullanım süresi, günlük cep telefonuyla konuşma süresi, günde kaç mesaj (sms) aldığı, günde kaç mesaj (sms) yolladıklarını sorgulayan 19 soruya yer verilmiştir.

\section{Siber Zorbalık Ölçeği}

Arıcak, Kınay ve Tanrıkulu (2012), tarafından geliştirilen ölçeğin yapı geçerliliği, açıklayıcı faktör analizi ile incelenmiştir. Analiz sonucunda ölçeğin tek faktörlü bir yapı sergilediği görülmüştür. Kaiser-Meyer-Olkin örneklem uygunluğu değeri .939 ve Bartlett Sphericity Testi Ki Kare değeri $9197.54(\mathrm{p}<.05)$ olarak bulunmuştur. Bulunan bu tek faktör toplam varyansın \% 50.58'ini açıklamaktadır. Bunun dışında çizgi grafiğindeki (screeplot) kırılma noktası incelendiğinde ölçeğin tek faktörlü bir yapıyı temsil ettiği görülmektedir. Faktör yüklerine bakıldığında.49 ile .82 arasında değiştiği görülmektedir. Bu değerler tek faktör için oldukça iyi bir değer olarak kabul edilmiştir. Ölçeğin Cronbach alfa katsayısı .95 olarak; test-tekrar güvenirlik katsayısı .70 $(n=103)$ olarak bulunmuştur. Ölçekten alınabilecek en düşük puan 24 en yüksek puan 96'dır. Puanların yüksek çıkması siber zorbalık davranışlarının yüksekliği anlamina gelmektedir.

\section{Siber Mağduriyet Ölçeği}

Arıcak, Tanrıkulu ve Kınay (2012), tarafından geliştirilen ölçeğin yapı geçerliliği açımlayıcı faktör analizi ile incelenmiş ve ölçeğin tek faktörlü bir yapı sergilediği görülmüştür. KaiserMeyer-Olkin örneklem uygunluk değeri .882 ve Bartlett Sphericity Testi Ki-Kare değeri 
$4374.93(\mathrm{p}<.05)$ olarak bulunmuştur. Ayrıca çizgi grafiğindeki (screeplot) kırılma noktası incelendiğinde de ölçeğin tek faktörlü bir yapıyı temsil ettiği görülmektedir. Bu tek faktör toplam varyansın \% 30.17'sini açıklamaktadır. Tek faktör altındaki maddelerin faktör yükleri .43 ile .67 arasındadır. Bu yük değerlerinin tek faktör için oldukça iyi değerler olduğu kabul edilmiştir. Ölçeğin tamamı için Cronbach alfa katsayısı .89 olarak, test-tekrar test güvenirlik katsayısı ise $.75(n=96)$ olarak bulunmuştur. Ölçekten alınabilecek en düşük puan 24 en yüksek puan 48'dır. Puanların yüksek çıkması siber mağduriyet durumunun yüksek olduğu anlamına gelmektedir.

\section{Sürekli Öfke-Öfke İfade Tarzı Ölçeği}

Sürekli Öfke-Öfke İfade Tarzı Ölçeği (SÖÖTÖ), öğrencilerin öfke ifade tarzlarını belirlemek amacıyla Spielberger ve arkadaşları (1983) tarafından geliştirilmiş olup (akt. Özer 1994) ergen ve yetişkinlere uygulanabilmekte; zaman kısıtlaması bulunmamaktadır. Ölçek, 34 maddelik dörtlü Likert tipi bir ölçektir. Ölçeğin, ilk 10 maddesi sürekli öfkeyi, sonraki 24 maddesi ise, öfke ifade tarzlarını ölçmektedir. Sürekli öfke, kişinin genelde kendini nasıl hissettiğini, ne derece öfke yaşadığını ifade etmektedir. Sürekli Öfke Ölçeği'nden alınabilecek en düşük puan 10, en yüksek puan 40'tır. Öfke İfade Tarzı Ölçeği, öfkenin içe vurumu, öfkenin dışa vurumu ve öfke kontrolü olmak üzere üç alt gruptan oluşmaktadır. Öfkenin içe vurumu, öfkenin dışa vurumu ve öfke kontrolü alt ölçeklerinden alınabilecek en düşük puan sekiz, en yüksek puan 32'dir. Orjinal ölçeğin Cronbach Alfa değeri .77 ile .88 arasındadır. Ölçeğin Türkçe’ye uyarlanması Özer (1994) tarafından yapılmış olup Cronbach alfa değerleri "öfke kontrolü” boyutu için .84; "öfkenin dışa vurumu” boyutu için .78 ve "öfkenin içe vurumu” boyutu için .62 olarak bulunmuştur (Özer 1994).

\section{Stresle Başa çıkma Tarzları Ölçeği}

Bireylerin stresle başa çıkmada kullandıkları tarzları ölçmek amacıyla Folkman ve Lazarus (1980) tarafından geliştirilmiş olan Başa Çıkma Yolları Envanterinden (Ways of Coping Inventory) hareketle Şahin ve Durak (1995) tarafından bireylerin stresle başa çıkmada kullandıkları tarzları ölçmek amacıyla geliştirilmiş bir ölçme aracıdır. Kendine güvenli yaklaşım (ör: "Ne olursa olsun direnme ve mücadele etme gücünü kendimde bulurum"), Çaresiz yaklaşım (ör: "Kendimi kapana sıkışmış gibi hissederim”), İyimser yaklaşım (ör: "Olaydan / Olaylardan olumlu bir şey çıkartmaya çalışırım"), Boyun eğici yaklaşım (ör: "Başa gelen çekilir diye düşünürüm”) ve Sosyal destek arama (ör: "Sorunun gerçek nedenini anlayabilmek için başkalarına danışırım") olmak üzere beş ayrı alt ölçekten oluşan SBTÖ'de toplam 30 madde yer almaktadır. Alt ölçeklerde yer alan madde sayısı ise Kendine güvenli yaklaşım için 7, Çaresiz yaklaşım için 8, İyimser yaklaşım için 5, Boyun eğici yaklaşım için 6 ve Sosyal destek arama için ise 4'tür. Puanların 0'la 3 arasında değiştiği dörtlü SBTÖ'de alt ölçek puanları her bir alt ölçekten alınan puanların ilgili alt ölçekteki madde sayısına bölünmesiyle elde edilmektedir. Bu durumda alt ölçeklerden alınabilecek en düşük ve en yüksek puanlar 0 ila 3 arasında değişmektedir. Alt ölçeklerden alınan puanların yüksek olması kişinin ilgili başa çıkma tarzını daha fazla kullandığ şeklinde yorumlanmaktadır. Alt ölçeklere ilişkin iç tutarlık katsayılarının ise: Kendine güvenli yaklaşım için .62 ila .80 , Çaresiz yaklaşım için .64 ila .73, İyimser yaklaşım için .49 ila .68, Boyun eğici yaklaşım için .47 ila .72 ve Sosyal destek arama için .45 ila 47 arasında değiştiği (Şahin \& Durak, 1995) bildirilmektedir. SBTÖ alt ölçekleri için bu çalışmada hesaplanan iç tutarlık katsayıları ise sırasıyla.74, 69, 66, 53 ve 53 olarak tespit edilmiştir.

\section{Boyun Eğici Davranışlar Ölçeği}

Depresyonla ilgili boyun eğici sosyal davranışları değerlendiren, 16 maddeden oluşan tek faktörlü bir ölçektir. Türkçe uyarlaması Şahin ve Şahin (1992) tarafından yapılmıştır. Ölçeğin 
Beck Depresyon Envanteri ile korelasyonu .32, Sosyopati Ölçeği ile .36 olarak bulunmuştur. İç tutarlılık .89, test-tekrar test güvenirliği .84 olarak saptanmıştır. Hem ergen, hem de yetişkinlere uygulanabilir. Her maddede sözü edilen davranışların kişiyi ne kadar iyi tanımladığı sorulmaktadır. Maddeler 1-5 arasında, 5’li Likert tipi puanlama esasına göre değerlendirilir. Ölçekten en düşük 11, en yüksek 80 puan alınabilir. Yüksek puanlar daha fazla boyun eğici davranışa işaret eder (Savaşır \& Şahin 1997).

\section{Verilerin Değerlendirilmesi}

Araştırmadan elde edilen veriler spss 21 istatistik programında değerlendirilmiştir. Araştırmaya katılanların demografik özelliklerinin frekans tablosu öncelikle oluşturulmuştur. Araştırmadan elde edilen verilerin istatistiksel değerlendirmesinde, bazı ölçeklerin p değerleri 0.05 den büyük olduğu için normal dağılıma uygun olduğu ve parametrik testler uygulanmış ayrıca örneklem sayıs1 30'dan küçük olan gruplarda nonparametrik testler kullanılarak demografik sorular ile ölçekler arasındaki ilişkiye bakılmıştır. Bazı ölçeklerinde p değerleri 0.05 'den küçük olduğu için normal dağılıma uygun olmadığından nonparametrik testler kullanılarak demografik sorular ile ölçekler arasındaki ilişkiye bakılmıştır. iki gruplu değişkenlerde Bağımsız Örneklem T testi, Mann Whitney U testi ikiden fazla gruplu değişkenlerde Kruskal Wallis testi ve ANOVA uygulanmıştır. Ölçekler arasında da anlamlı ilişkiler olup olmadığını test etmek için de normal dağ 11 ım gösterenlerde pearson korelasyon, normal dağılım göstermeyenlerde spearman korelasyon testleri uygulanarak analiz edilmiştir.

\section{Bulgular}

Tablo 3. Bireylerin Cinsiyeti ile Siber Zorbalık Ölçeği ve Siber Mağduriyet Ölçeği Puanları Açısından "Mann Whitney U" Testi İle Karşılaştırılması

\begin{tabular}{llllll}
\hline Cinsiyet & & $\mathbf{N}$ & $\begin{array}{l}\text { Sura } \\
\text { Ortalaması }\end{array}$ & $\boldsymbol{X}^{2}$ & P \\
\hline \multirow{2}{*}{ Siber zorbalık ölçeği } & Kız & 293 & 233.81 & 25434.00 & .000* \\
& Erkek & $\mathbf{2 1 3}$ & $\mathbf{2 8 0 . 5 9}$ & & \\
\hline Siber mağduriyet ölçeği & Kız & 293 & 260.55 & 29140.00 & .180 \\
\hline$*$ P $<0.05$ & Erkek & 213 & 243.81 & & \\
\hline
\end{tabular}

Tablo 3’te görüldüğ̈̈ gibi Bireylerin cinsiyetleri arasında siber zorbalık ölçeği puanı açısından istatistiksel olarak anlamlı fark bulunmaktadır. $(p<0,05)$. Buna göre siber zorbalık ölçeği cinsiyet değişkenine göre farklılık yaratmaktadır. Cinsiyete göre siber zorbalık puanları açısından erkekler (sıralama ortalaması $=280.59$ ) ve kızlar (sıralama ortalaması $=233.81$ ) arasında erkeklerin lehine anlamlı bir fark vardır $[U=25434.00, p=.000]$.

Bireylerin cinsiyetleri arasında siber mağduriyet ölçeği puanı açısından istatistiksel olarak anlamlı fark bulunmamaktadır. ( $\mathrm{p}>0,05)$. Buna göre siber mağduriyet ölçeği cinsiyet değişkenine göre farklılık yaratmamaktadır. Cinsiyete göre siber mağduriyet puanları açısından kızlar (siralama ortalaması $=260.55$ ) ve erkekler (siralama ortalaması $=243.81)$ arasinda anlamlı bir fark yoktur [U=29140.00, $\mathrm{p}=.180]$. 
Tablo 4. Bireylerin Yaşı ile Siber Zorbalık Ölçeği ve Siber Mağduriyet Ölçeği Puanları Açısından "Kruskal Wallis H" Testi İle Karşılaştırılması

\begin{tabular}{|c|c|c|c|c|c|}
\hline Yaş & & $\mathbf{N}$ & $\begin{array}{c}\text { Sira } \\
\text { Ortalaması } \\
\end{array}$ & $X^{2}$ & $\mathbf{P}$ \\
\hline Siber zorbalık ölçeği & $\begin{array}{l}19 \text { yaşında } \\
18 \text { yaşında } \\
17 \text { yaşında } \\
16 \text { yaşında } \\
15 \text { yaşında }\end{array}$ & $\begin{array}{c}36 \\
71 \\
151 \\
137 \\
111\end{array}$ & $\begin{array}{l}201.40 \\
235.08 \\
259.06 \\
271.84 \\
251.98\end{array}$ & 9.29 & .054 \\
\hline Siber mağduriyet ölçeği & $\begin{array}{l}19 \text { yaşında } \\
18 \text { yaşında } \\
17 \text { yaşında } \\
16 \text { yaşında } \\
15 \text { yaşında }\end{array}$ & $\begin{array}{c}36 \\
71 \\
151 \\
137 \\
111\end{array}$ & $\begin{array}{l}217.26 \\
239.91 \\
258.52 \\
270.41 \\
246.25\end{array}$ & 5.67 & .225 \\
\hline
\end{tabular}

Tablo 4'de görüldüğü gibi Bireylerin yaşları arasında siber zorbalık ölçeği puanı açısından istatistiksel olarak anlamlı fark bulunmamaktadır. $(\mathrm{p}>0,05)$. Buna göre siber zorbalık ölçeği yaş değişkenine göre farklılık yaratmamaktadır. Siber zorbalık puanları açısından yaşlar arasında anlamlı bir fark yoktur [k-w=9.29, $\mathrm{p}=.054]$.

Bireylerin yaşlanı arasında siber mağduriyet ölçeği puanı açısından istatistiksel olarak anlamlı fark bulunmamaktadır. ( $p>0,05)$. Buna göre siber mağduriyet ölçeği yaş değişkenine göre farklılık yaratmamaktadır. Siber mağduriyet puanları açısından yaş arasında anlamlı bir fark yoktur [k-w= 5.67, $\mathrm{p}=.225]$.

Tablo 5. Bireylerin Okuduğu Okul ile Siber Zorbalık Ölçeği ve Siber Mağduriyet Ölçeği Puanları Açısından "Kruskal Wallis H" Testi İle Karşılaştırılması

\begin{tabular}{llllll}
\hline Okul & & N & $\begin{array}{l}\text { Sıra } \\
\text { Ortalaması }\end{array}$ & $\boldsymbol{X}^{\mathbf{2}}$ & P \\
\hline Siber zorbalık & Güç Kardeşler Anadolu Lisesi & 152 & 273.39 & & \\
ölçeği & Atatürk Endüstri Meslek Lisesi & 155 & 252.21 & 5.40 & .067 \\
& Nesrin Uçmaklığlu T. M. L & 199 & 239.31 & & \\
\hline Siber & Güç Kardeşler Anadolu Lisesi & 152 & 243.35 & & .555 \\
mağduriyet & AtatürkEndüstri Meslek Lisesi & 155 & 256.69 & 1.17 & \\
ölçeği & Nesrin Uçmaklığlu T. M. L & 199 & 258.62 & & \\
\hline
\end{tabular}

Tablo 5'de görüldüğü gibi Bireylerin okudukları okullar arasında siber zorbalık ölçeği puanı açısından istatistiksel olarak anlamlı fark bulunmamaktadır. ( $p>0,05)$. Buna göre siber zorbalık ölçeği okul değişkenine göre farklılık yaratmamaktadır. Siber zorbalık puanları açısından yaşlar arasinda anlamlı bir fark yoktur [k-w=5.40, $\mathrm{p}=.067]$.

Bireylerin okudukları okullar arasında siber mağduriyet ölçeği puanı açısından istatistiksel olarak anlamlı fark bulunmamaktadır. $(\mathrm{p}>0,05)$. Buna göre siber mağduriyet ölçeği yaş değişkenine göre farklılık yaratmamaktadır. Siber mağduriyet puanları açısından okul arasında anlamlı bir fark yoktur [k-w=1.17, $\mathrm{p}=.555]$. 
Tablo 6. Bireylerin Kaçıncı Sınıfta Okuduğu ile Siber Zorbalık Ölçeği ve Siber Mağduriyet Ölçeği Puanları Açısından “Kruskal Wallis H” Testi İle Karşılaştırılması

\begin{tabular}{|c|c|c|c|c|c|}
\hline Sinıf & & $\mathbf{N}$ & $\begin{array}{l}\text { Sira } \\
\text { Ortalaması }\end{array}$ & $X^{2}$ & $\mathbf{P}$ \\
\hline \multirow{4}{*}{ Siber zorbalık ölçeği } & 9. sinif & 138 & 252.18 & \multirow{4}{*}{7.99} & \multirow{4}{*}{$.046^{*}$} \\
\hline & 10. sinif & 147 & 255.60 & & \\
\hline & 11. sinif & 142 & 272.20 & & \\
\hline & 12. sinif & 79 & 218.27 & & \\
\hline \multirow{4}{*}{ Siber mağduriyet ölçeği } & 9. sinif & 138 & 247.76 & \multirow{4}{*}{7.97} & \multirow{4}{*}{$.047 *$} \\
\hline & 10. sinif & 147 & 267.65 & & \\
\hline & 11. sinif & 142 & 264.46 & & \\
\hline & 12. sinif & 79 & 217.49 & & \\
\hline
\end{tabular}

Tablo 6'da görüldüğü gibi Bireylerin kaçıncı sınıfta okudukları arasında siber zorbalık ölçeği puanı açısından istatistiksel olarak anlamlı fark bulunmaktadır. $(p<0,05)$. Buna göre siber zorbalık ölçeği sınıf değişkenine göre farklılık yaratmaktadır. Siber zorbalık ölçeği puanları açısından 11. sınıfta okuyan bireylerin lehine anlamlı bir fark vardır [ $k-w=7.99, p=.046]$.

Bireylerin kaçıncı sınıfta okudukları arasında siber mağduriyet ölçeği puanı açısından istatistiksel olarak anlamlı fark bulunmaktadır. $(p<0,05)$. Buna göre siber mağduriyet ölçeği sınıf değişkenine göre farklılık yaratmaktadır. Siber mağduriyet puanları açısından 10. sınıfta okuyan bireylerin lehine anlamlı bir fark vardır [k-w=7.97, $p=.047]$.

Tablo 7. Bireylerin Annelerinin Eğitim Düzeyi ile Siber Zorbalık Ölçeği ve Siber Mağduriyet Ölçeği Puanları Açısından “Kruskal Wallis H” Testi İle Karşılaştırılması

\begin{tabular}{|c|c|c|c|c|c|}
\hline Eğitim & & $\mathbf{N}$ & Sira Ortalaması & $X^{2}$ & $\mathbf{P}$ \\
\hline \multirow{5}{*}{ Siber zorbalık ölçeği } & Okur-yazar değil & 22 & 242.75 & \multirow{5}{*}{5.86} & \multirow{5}{*}{.209} \\
\hline & İlkokul mezunu & 251 & 242.73 & & \\
\hline & Ortaokul mezunu & 114 & 253.28 & & \\
\hline & Lise mezunu & 94 & 281.26 & & \\
\hline & Üniversite ve üstü mezunu & 25 & 267.76 & & \\
\hline \multirow{5}{*}{$\begin{array}{l}\text { Siber mağduriyet } \\
\text { ölçeği }\end{array}$} & Okur-yazar değil & 22 & 289.52 & \multirow{5}{*}{3.34} & \multirow{5}{*}{.501} \\
\hline & İlkokul mezunu & 251 & 246.73 & & \\
\hline & Ortaokul mezunu & 114 & 264.34 & & \\
\hline & Lise mezunu & 94 & 255.48 & & \\
\hline & Üniversite ve üstü mezunu & 25 & 232.92 & & \\
\hline
\end{tabular}

Tablo 7’de görüldüğü gibi bireylerin annelerinin eğitim düzeyleri arasında siber zorbalık ölçeği puanı açısından istatistiksel olarak anlamlı fark bulunmamaktadır. ( $p>0,05)$. Buna göre siber zorbalık ölçeği eğitim değişkenine göre farklılık yaratmamaktadır. Siber zorbalık ölçeği puanları açısından bireylerin annelerinin eğitim düzeyleri arasında anlamlı bir fark yoktur $[\mathrm{k}-\mathrm{w}=5.86$, $\mathrm{p}=.209]$.

Bireylerin annelerinin eğitim düzeyleri arasında siber mağduriyet ölçeği puanı açısından istatistiksel olarak anlamlı fark bulunmamaktadır. $(p>0,05)$. Buna göre siber mağduriyet ölçeği eğitim değişkenine göre farklılık yaratmamaktadır. Siber mağduriyet puanları açısından bireylerin annelerinin eğitim düzeyleri arasında anlamlı bir fark yoktur [k-w=3.34, $\mathrm{p}=.501]$. 
Tablo 8. Bireylerin Babalarının Eğitim Düzeyi ile Siber Zorbalık Ölçeği ve Siber Mağduriyet Ölçeği Puanları Açısından “Kruskal Wallis H” Testi İle Karşılaştırılması

\begin{tabular}{|c|c|c|c|c|c|}
\hline Eğitim & & $\mathbf{N}$ & $\begin{array}{l}\text { Sira } \\
\text { Ortalaması }\end{array}$ & $X^{2}$ & $\mathbf{P}$ \\
\hline \multirow{4}{*}{ Siber zorbalık ölçeği } & İlkokul mezunu & 198 & 234.21 & \multirow{4}{*}{9.26} & \multirow{4}{*}{$.026 *$} \\
\hline & Ortaokul mezunu & 121 & 267.49 & & \\
\hline & Lise mezunu & 139 & 255.19 & & \\
\hline & Üniversite ve üstü mezunu & 48 & 292.91 & & \\
\hline \multirow{4}{*}{$\begin{array}{l}\text { Siber mağduriyet } \\
\text { ölçeği }\end{array}$} & İlkokul mezunu & 198 & 248.23 & & \\
\hline & Ortaokul mezunu & 121 & 278.16 & \multirow{3}{*}{5.18} & \multirow{3}{*}{.159} \\
\hline & Lise mezunu & 139 & 242.06 & & \\
\hline & Üniversite ve üstü mezunu & 48 & 246.19 & & \\
\hline
\end{tabular}

Tablo 8'de görüldüğü gibi bireylerin babalarının eğitim düzeyleri arasında siber zorbalık ölçeği puanı açısından istatistiksel olarak anlamlı fark bulunmaktadır. $(\mathrm{p}<0,05)$. Buna göre siber zorbalık ölçeği eğitim değişkenine göre farklılık yaratmaktadır. Siber zorbalık ölçeği puanları açısından babası üniversite mezunu olan bireylerin lehine anlamlı bir fark vardır [k$w=9.26, p=.026]$.

Bireylerin babalarının eğitim düzeyleri arasında siber mağduriyet ölçeği puanı açısından istatistiksel olarak anlamlı fark bulunmamaktadır. ( $p>0,05)$. Buna göre siber mağduriyet ölçeği eğitim değişkenine göre farklılık yaratmamaktadır. Siber mağduriyet puanları açısından bireylerin babalarının eğitim düzeyleri arasında anlamlı bir fark yoktur [k-w=5.18, $\mathrm{p}=.159]$.

Tablo 9. Bireylerin Ailelerinin Gelir Düzeyi ile Siber Zorbalık Ölçeği ve Siber Mağduriyet Ölçeği Puanları Açısından “Kruskal Wallis $H$ ” Testi İle Karşılaştırılması

\begin{tabular}{llllll}
\hline Gelir & & N & Sira Ortalaması & $\boldsymbol{X}^{\mathbf{2}}$ & P \\
\hline \multirow{3}{*}{ Siber zorbalık ölçeği } & Düşük & 21 & 277.14 & & \\
& Orta & 251 & 244.47 & & \multirow{2}{*}{. } \\
& İyi & 211 & 261.06 & 2.45 & .484 \\
& Çok iyi & 23 & 261.09 & & \\
\hline \multirow{4}{*}{ Siber mağduriyet ölçeği } & Düsük & 21 & 254.93 & & \\
& Orta & 251 & 254.72 & \multirow{2}{*}{3.42} & .330 \\
& İyi & 211 & 257.57 & & \\
& Çok iyi & 23 & 201.54 & & \\
\hline
\end{tabular}

Tablo 9'da görüldüğü gibi bireylerin ailelerinin gelir düzeyleri arasında siber zorbalık ölçeği puanı açısından istatistiksel olarak anlamlı fark bulunmamaktadır. $(\mathrm{p}>0,05)$. Buna göre siber zorbalık ölçeği gelir değişkenine göre farklılık yaratmamaktadır. Siber zorbalık ölçeği puanları açısından bireylerin ailelerinin gelir düzeyleri anlamlı bir fark yoktur [k-w=2.45, $\mathrm{p}=.484]$.

Bireylerin ailelerinin gelir düzeyleri arasında siber mağduriyet ölçeği puanı açısından istatistiksel olarak anlamlı fark bulunmamaktadır. ( $p>0,05)$. Buna göre siber mağduriyet ölçeği gelir değişkenine göre farklılık yaratmamaktadır. Siber mağduriyet puanları açısından bireylerin ailelerinin gelir düzeyleri arasında anlamlı bir fark yoktur [k-w=3.42, $\mathrm{p}=.330]$. 
Tablo 10. Bireylerin Okul Başarı Düzeyleri ile Siber Zorbalık Ölçeği ve Siber Mağduriyet Ölçeği Puanları Açısından “Kruskal Wallis H” Testi İle Karşılaştııılması

\begin{tabular}{llllll}
\hline & Başarı & $\mathbf{N}$ & Sıra Ortalaması & $\boldsymbol{X}^{2}$ & $\mathbf{P}$ \\
\hline & Düşük & 32 & 275.53 & & \\
Siber zorbalık ölçeği & Orta & 240 & 265.60 & & \\
& İyi & 190 & 242.40 & & \\
& Çok iyi & 44 & 219.39 & 6.73 & .081 \\
& & & & & \\
Siber mağduriyet ölçeği & Düşük & $\mathbf{3 2}$ & $\mathbf{2 8 8 . 4 5}$ & & \\
& Orta & 240 & 271.62 & & \\
& İyi & 190 & 232.26 & & \\
& Çok iyi & 44 & 220.93 & & \\
\hline
\end{tabular}

${ }^{*} \mathrm{p}<0.05$

Tablo 10'da görüldüğü gibi bireylerin okul başarı düzeyleri arasında siber zorbalık ölçeği puanı açısından istatistiksel olarak anlamlı fark bulunmamaktadır. ( $p>0,05)$. Buna göre siber zorbalık ölçeği başarısı değişkenine göre farklılık yaratmaktadır. Siber zorbalık ölçeği puanları açısından bireylerin okul başarı düzeyleri arasında anlamlı bir fark yoktur [k-w=6.73, $\mathrm{p}=.081]$.

Bireylerin okul başarı düzeyleri arasında siber mağduriyet ölçeği puanı açısından istatistiksel olarak anlamlı fark bulunmaktadır. $(p<0,05)$. Buna göre siber mağduriyet ölçeği başarı değişkenine göre farklılık yaratmaktadır. Siber mağduriyet puanları açısından okul başarısı düşük olan bireylerin lehine anlamlı bir fark vardır [ $k-w=13.00, p=.005]$.

Tablo 11. Bireylerin Kendine Ait Bilgisayarın Olup Olmaması ile Siber Zorbalık Ölçeği ve Siber Mağduriyet Ölçeği Puanları Açısından "Mann Whitney U” Testi İle Karşılaştırılması

\begin{tabular}{llllll}
\hline & Bilgisayar & N & $\begin{array}{l}\text { Sıra } \\
\text { Ortalaması }\end{array}$ & $\boldsymbol{X}^{2}$ & P \\
\hline \multirow{2}{*}{ Siber zorbalık ölçeği } & Evet & 381 & 259.70 & 21448.50 & .074 \\
& Hayır & 125 & 234.59 & & \\
\hline \multirow{2}{*}{ Siber mağduriyet ölçeği } & Evet & 381 & 252.06 & 23262.50 & .683 \\
& Hayır & 125 & 257.90 & & \\
\hline
\end{tabular}

$* \mathrm{P}<0.05$

Tablo 11'de görüldügü gibi bireylerin kendilerine ait bilgisayarının olup olmaması arasında siber zorbalık ölçeği puanı açısından istatistiksel olarak anlamlı fark bulunmamaktadır. $(\mathrm{p}>0,05)$. Buna göre siber zorbalık ölçeği bilgisayar değişkenine göre farklılık yaratmamaktadır.

Bireylerin kendilerine ait bilgisayarının olup olmaması arasında siber mağduriyet ölçeği puanı açısından istatistiksel olarak anlamlı fark bulunmamaktadır. ( $p>0,05)$. Buna göre siber mağduriyet ölçeği bilgisayar değişkenine göre farklılık yaratmamaktadır. 
Tablo 12. Bireylerin Kullandığı E-mail Adreslerinde Kendi İsimlerinin Olup Olmaması ile Siber Zorbalık Ölçeği ve Siber Mağduriyet Ölçeği Puanları Açısından "Mann Whitney U" Testi İle Karşılaştırılması

\begin{tabular}{llllll}
\hline & E-mail & N & $\begin{array}{l}\text { Sira } \\
\text { Ortalaması }\end{array}$ & $\boldsymbol{X}^{2}$ & \multicolumn{2}{c}{ P } \\
\hline \multirow{2}{*}{ Siber zorbalık ölçeği } & Evet & 370 & 260.09 & 24942.50 & .340 \\
& Hayır & 142 & 247.15 & & \\
\hline \multirow{2}{*}{ Siber mağduriyet ölçeği } & Evet & 370 & 259.95 & 24992.00 & .368 \\
\hline$* \mathrm{P}<0.05$ & Hayır & 142 & 247.50 & & \\
\hline
\end{tabular}

Tablo 12'de görüldüğü gibi bireylerin e-mail adreslerinde kendi isimlerinin olup olmamas1 arasında siber zorbalık ölçeği puanı açısından istatistiksel olarak anlamlı fark bulunmamaktadır. $(p>0,05)$. Buna göre siber zorbalık ölçeği e-mail adresininde isimlerinin olup olmamasına göre farklılık yaratmamaktadır.

Bireylerin e-mail adreslerinde kendi isimlerinin olup olmaması arasında siber mağduriyet ölçeği puanı açısından istatistiksel olarak anlamlı fark bulunmamaktadır. (p>0,05). Buna göre siber mağduriyet ölçeği e-mail adreslerinde kendi isimlerinin olup olmamasına göre farklılık yaratmamaktadır.

Tablo 13. Bireylerin Bilgisayar Oyunu Oynayıp Oynamama Durumu ile Siber Zorbalık Ölçeği ve Siber Mağduriyet Ölçeği Puanları Açısından "Mann Whitney U” Testi İle Karşılaştırılması

\begin{tabular}{llllll}
\hline Bilgisayar oyunu & & $\mathbf{N}$ & $\begin{array}{l}\text { Sira } \\
\text { Ortalaması }\end{array}$ & $\boldsymbol{X}^{2}$ & $\mathbf{P}$ \\
\hline \multirow{2}{*}{ Siber zorbalık ölçeği } & Evet & $\mathbf{3 0 9}$ & $\mathbf{2 7 2 . 6 1}$ & 26385.00 & \multirow{2}{*}{$\mathbf{. 0 0 1 *}$} \\
& Hayır & 203 & 231.98 & & \\
\hline \multirow{2}{*}{ Siber mağduriyet ölçeği } & Evet & 309 & 257.68 & 30997.50 & .814 \\
& Hayır & 203 & 254.70 & & \\
\hline$* \mathrm{P}<0.05$ & & & & &
\end{tabular}

$* \mathrm{P}<0.05$

Tablo 13'de görüldügü gibi bireylerin bilgisayar oyunu oynayıp oynamaması arasında siber zorbalık ölçeği puanı açısından istatistiksel olarak anlamlı fark bulunmaktadır. $(p<0,05)$. Buna göre siber zorbalık ölçeği bireylerin bilgisayar oyunu oynayıp oynamamasına göre farklılık yaratmaktadır. Bireylerin bilgisayar oyunu oynayıp oynamamasına göre siber zorbalık ölçeği puanları açısından oynayan bireyler $(X=272.61)$ ve oynamayan bireyler $(X=231.98)$ arasında bilgisayar oyunu oynayan bireylerin lehine anlamlı bir fark vardır $[\mathrm{U}=\mathbf{- 2 6 3 8 5 . 0 0 \text { , }}$ $\mathbf{p}=.001]$.

Bireylerin bilgisayar oyunu oynayıp oynamaması arasında siber mağduriyet ölçeği puanı açısından istatistiksel olarak anlamlı fark bulunmamaktadır. ( $p>0,05)$. Buna göre siber mağduriyet ölçeği bireylerin bilgisayar oyunu oynayıp oynamamasına göre farklılık yaratmamaktadır. 
Tablo 14. Bireylerin Ne Kadar Süre İnternette Girdiği ile Siber Zorbalık Ölçeği ve Siber Mağduriyet Ölçeği Puanları Açısından “Kruskal Wallis H” Testi İle Karşılaştırılması

\begin{tabular}{|c|c|c|c|c|c|}
\hline & Süre & $\mathbf{N}$ & Sura Ortalaması & $X^{2}$ & $\mathbf{P}$ \\
\hline \multirow{6}{*}{$\begin{array}{l}\text { Siber zorbalık } \\
\text { ölçeği }\end{array}$} & Girmiyor & 31 & 192.76 & \multirow{6}{*}{14.91} & \multirow{6}{*}{$.011^{*}$} \\
\hline & 1 saat & 115 & 240.40 & & \\
\hline & 2 saat & 141 & 250.34 & & \\
\hline & 3 saat & 99 & 281.77 & & \\
\hline & 4 saat & 58 & 260.80 & & \\
\hline & 5 saat & 68 & 285.11 & & \\
\hline \multirow{6}{*}{$\begin{array}{l}\text { Siber } \\
\text { mağduriyet } \\
\text { ölçeği }\end{array}$} & Girmiyor & 31 & 230.44 & \multirow{6}{*}{10.30} & \multirow{6}{*}{.067} \\
\hline & 1 saat & 115 & 224.15 & & \\
\hline & 2 saat & 141 & 270.07 & & \\
\hline & 3 saat & 99 & 265.64 & & \\
\hline & 4 saat & 58 & 264.26 & & \\
\hline & 5 saat & 68 & 275.04 & & \\
\hline
\end{tabular}

${ }^{*} \mathrm{p}<0.05$

Tablo 14'de görüldüğü gibi bireylerin ne kadar süre internette girdikleri arasında siber zorbalık ölçeği puanı açısından istatistiksel olarak anlamlı fark bulunmaktadır. $(p<0,05)$. Buna göre siber zorbalık ölçeği internet süresi göre farklılık yaratmaktadır. Siber zorbalık ölçeği puanları açısından günlük 5 saat ve üzerinde internete giren bireylerin lehine anlamlı bir fark vardır [k-w=14.91, $\mathrm{p}=.011]$.

Bireylerin ne kadar süre internette girdikleri arasında siber mağduriyet ölçeği puanı açısından istatistiksel olarak anlamlı fark bulunmamaktadır. $(\mathrm{p}>0,05)$. Buna göre siber mağduriyet ölçeği internette girme süresi değişkenine göre farklılık yaratmamaktadır. Siber mağduriyet puanları açısından ne kadar süre internette girdikleri arasında anlamlı bir fark yoktur $[\mathrm{k}-\mathrm{w}=10.30, \mathrm{p}=.067]$.

Tablo 15. Bireylerin Sahip Olduğu Davranış Biçimi ile Siber Zorbalık Ölçeği ve Siber Mağduriyet Ölçeği Puanları Açısından "Kruskal Wallis H" Testi İle Karşılaştırılması

\begin{tabular}{|c|c|c|c|c|c|}
\hline Davranış & & $\mathbf{N}$ & Sira Ortalaması & $X^{2}$ & $\mathbf{P}$ \\
\hline \multirow{4}{*}{ Siber zorbalık ölçeği } & Sakin & 224 & 257.65 & & \\
\hline & Saldırgan & 39 & 312.51 & & \\
\hline & Girișken & 151 & 252.79 & & \\
\hline & Çekingen & 98 & 237.31 & 8.53 & $.036 *$ \\
\hline \multirow{4}{*}{ Siber mağduriyet ölçeği } & Sakin & 224 & 242.12 & & \multirow{4}{*}{.230} \\
\hline & Saldırgan & 39 & 266.77 & \multirow{3}{*}{4.30} & \\
\hline & Girisken & 151 & 270.27 & & \\
\hline & Çekingen & 98 & 264.07 & & \\
\hline
\end{tabular}

${ }^{*} \mathrm{p}<0.05$

Tablo 15'de görüldüğü gibi bireylerin sahip olduğu davranış biçimi arasında siber zorbalık ölçeği puanı açısından istatistiksel olarak anlamlı fark bulunmaktadır. $(\mathrm{p}<0,05)$. Buna göre siber zorbalık ölçeği davranış biçimine göre farklılık yaratmaktadır. Siber zorbalık ölçeği puanları açısından çekingen olan bireylerin lehine anlamlı bir fark vardır [ $k-w=8.53, p=.000]$.

Bireylerin sahip olduğu davranış biçimi arasında siber mağduriyet ölçeği puanı açısından istatistiksel olarak anlamlı fark bulunmamaktadır. ( $p>0,05$ ). Buna göre siber mağduriyet ölçeği davranış biçimi değişkenine göre farklılık yaratmamaktadır. Siber mağduriyet puanları açısın- 
dan sahip olduğu davranış biçimi arasında anlamlı bir fark yoktur $[\mathrm{k}-\mathrm{w}=4.30, \mathrm{p}=2.30]$.

Bireylerin siber zorbalık ölçeği ile stresle başa çıkma envanteri alt ölçekleri, sürekli öfke ölçeğinin alt ölçekleri ve boyun eğme davranış ölçeğinin toplam puanları arasındaki ilişki incelendiğinde; siber zorbalık ölçeği puanı ile dış yardım arama ölçeği puanı $(r=-.066 \mathrm{p}<0.05)$, aktif planlama ölçeği puanı $(r=-.178 p<0.05)$, yeniden yapılandırma ölçeği puanı $(r=-.098$ $\mathrm{p}<0.05)$, sürekli öfke ölçeği puanı $(\mathrm{r}=.213 \mathrm{p}<0.05)$, öfkenin içe vurumu ölçeği puanı $(\mathrm{r}=.164$ $\mathrm{p}<0.05)$, öfkenin dışa vurumu ölçeği puanı $(\mathrm{r}=.271 \mathrm{p}<0.05)$ arasında istatistiksel olarak anlamlı ilişki bulunmuştur. Buna göre siber zorbalık puanı arttıkça dış yardım arama ölçeğinden, aktif planlama ölçeğinden, yeniden yapılandırma ölçeğinden alınan puan düşmektedir ve sürekli öfke ölçeğinden, öfkenin içe vurumu ölçeğinden, öfkenin dışa vurumu ölçeğinden alınan puan da artmaktadır.

Siber zorbalık ölçeği puanı ile dine sığınma ölçeği puanı ( $\mathrm{r}=-.052 \mathrm{p}>0.05)$, kaçma soyutlama duygusal ölçeği puanı ( $\mathrm{r}=-.065 \mathrm{p}>0.05)$, öfke kontorü ölçeği puanı $(\mathrm{r}=-.074 \mathrm{p}>0.05)$, boyun eğici davranış ölçeği puanı $(\mathrm{r}=.022 \mathrm{p}>0.05)$ arasında istatistiksel olarak anlamlı ilişki bulunmamıştır.

Bireylerin siber mağduriyet ölçeği ile stresle başa çıkma envanterinin alt ölçekleri, sürekli öfke ölçeğinin alt ölçekleri ve boyun eğici davranış ölçeği toplam puanları arasındaki ilişki incelendiğinde; siber mağduriyet ölçeği puanı ile kaçma soyutlama duygusal ölçeği puanı $(\mathrm{r}=.089 \mathrm{p}<0.05)$, sürekli öfke ölçeği puanı $(\mathrm{r}=.170 \mathrm{p}<0.05)$, öfkenin içe vurumu ölçeği puanı $(\mathrm{r}=.138 \mathrm{p}<0.05)$, öfkenin dışa vurumu ölçeği puanı $(\mathrm{r}=.180 \mathrm{p}<0.05)$ arasında istatistiksel olarak anlamlı ilişki bulunmuştur. Buna göre siber mağduriyet puanı arttıkça kaçma soyutlama duygusal ölçeğinden, sürekli öfke ölçeğinden, öfkenin içe vurumu ölçeğinden, öfkenin dışa vurumu ölçeğinden alınan puan da artmaktadır.

Araştırma sonuçlarına göre siber mağduriyet ölçeği puanı ile dış yardım arama ölçeği puanı $(\mathrm{r}=.022 \mathrm{p}>0.05)$, dine sığınma ölçeği puanı $(\mathrm{r}=-.075 \mathrm{p}>0.05)$, aktif planlama ölçeği puanı $(\mathrm{r}=$ $.066 \mathrm{p}>0.05)$, yeniden yapılandırma ölçeği puanı $(\mathrm{r}=.012 \mathrm{p}>0.05)$, öfke kontrolü ölçeği puanı $(\mathrm{r}=-.085 \mathrm{p}>0.05)$, boyun eğici davranış ölçeği puanı $(\mathrm{r}=.066 \mathrm{p}>0.05)$ arasında istatistiksel olarak anlamlı ilişki bulunmamıştır.

Bireylerin boyun eğici davranış ölçeği ile stresle başa çıkma envanterinin alt ölçekleri ve sürekli öfke ölçeğinin alt ölçekleri arasındaki ilişki incelendiğinde; boyun eğici davranış ölçeği puanı ile dış yardım arama ölçeği puanı $(\mathrm{r}=142 . \mathrm{p}<0.05)$, dine sı̆̆ınma ölçeği puanı $(\mathrm{r}=.155$ $\mathrm{p}<0.05)$, aktif planlama ölçeği puanı $(\mathrm{r}=.138 \mathrm{p}<0.05)$, kaçma soyutlama duygusal ölçeği puanı $(\mathrm{r}=.227 \mathrm{p}<0.05)$, yeniden yapılandırma ölçeği puanı $(\mathrm{r}=.22 \mathrm{p}<0.05)$, sürekli öfke ölçeği puanı $(\mathrm{r}=.167 \mathrm{p}<0.05)$, öfkenin içe vurumu ölçeği puanı $(\mathrm{r}=.351 \mathrm{p}<0.05)$, öfkenin dişa vurumu ölçeği puanı $(\mathrm{r}=.107 \mathrm{p}<0.05)$, öfke kontrolü ölçeği puanı $(\mathrm{r}=.181 \mathrm{p}<0.05)$ arasında istatistiksel olarak anlamlı ilişki bulunmuştur. Buna göre boyun eğici davranış puanı arttıkça dış yardım arama ölçeğinden, dine sığınma ölçeğinden, aktif planlama ölçeğinden, kaçma soyutlama duygusal ölçeğinden, yeniden yapılandırma ölçeğinden, sürekli öfke ölçeğinden, öfkenin içe vurumu ölçeğinden, öfkenin dışa vurumu ölçeğinden, öfke kontrolü ölçeğinden alınan puan da artmaktadir.

\section{Tartışma, Sonuç ve Öneriler}

Araştırmada siber zorbalığın / siber mağduriyetin cinsiyete göre farklılaşıp farklılaşmadığ incelendiğinde cinsiyete göre siber zorbalık puanları açısından erkekler ve kızlar arasında erkeklerin lehine anlamlı bir fark vardır. Yapılan literatür araştırmalarında kızların erkeklerden hem daha az siber zorbalık yaptığı hem de daha az siber mağdur oldukları bulunmuştur (Li 2006; Arıcak 2009; Eroğlu \& Peker 2011). Ancak Hinduja ve Patchin'in (2008) araştırma sonuçları, kızların siber zorbalık olaylarına erkeklerden çok daha uzun süreçlerde dahil oldukları 
yönünde olmakla birlikte bulgularımızla çelişir niteliktedir (Hinduja \& Patchin 2007).

Araştırmada öğrencilerin yaşları arasında siber mağduriyet ölçeği puanı açısından istatistiksel olarak anlamlı fark bulunmamaktadır. Buna göre siber mağduriyet ölçeği yaş değişkenine göre farklılık yaratmamaktadır.

Literatürde yaş ve siber zorbalık arasındaki ilişkiyi araştıran çalışmalarda farklı sonuçlar görülebilmektedir. Bazı araştırmacılar yaşın artışıyla birlikte öğrencilerin iletişim teknolojilerine daha rahat ulaşabildiklerini; bu teknolojik araçları ve interneti kullanma konusunda yeteneklerini daha fazla geliştirdiklerini; bu nedenle daha fazla siber zorbalık yaptıklarını düşünmektedirler (Ybarra 2004; Campbell 2005; Kowalski \& Limber 2007).

$\mathrm{Bu}$ araştırma sonucunda yaş gruplarına göre siber zorbalık puanları arasında anlamlı bir farklılık bulunmamıştır. Beran ve Li (2005), Erdur-Baker ve Kavşut (2007), Smith ve arkadaşları (2006), Eroğlu ve Peker (2011), Çivilidağ ve Cooper (2013) yapmış oldukları araştırmalarında da siber zorbalık açısından yaş grupları arasında anlamlı bir farklılık olmadığını ortaya koymuşlardır. Dolayısıyla araştırma sonucumuz, söz konusu araştırma sonuçlarıyla tutarlılık göstermektedir (Beran \& Li 2005; Smith et al. 2006; Erdur-Baker \& Kavşut 2007; Eroğlu \& Peker 2011).

Araştırmada öğrencilerin okudukları okullar arasında siber mağduriyet ölçeği puanı açısından istatistiksel olarak anlamlı fark bulunmamaktadır.

Literatür araştırma kapsamında bulunan Ticaret Meslek Lisesi ve meslek liselerinin web tasarımı gibi yoğun bilgisayar kullanımı gerektiren alanlarında okuyan öğrencilerin, bilişim teknolojilerini çok sık kullanması, mağdur olmalarının bir nedeni olarak görülmektedir. Topçu, Erdur-Baker, Çapa-Aydın (2008), özel okuldaki bilgi ve iletişim teknolojilerini kullanan öğrencilerin devlet okullarında okuyan öğrencilere göre daha fazla siber zorbalık yaptıklarını, Baker'in (2010), internet ve internet temelli iletişim kaynaklarının kullanımı ile siber mağduriyet arasında pozitif yönlü bir ilişki olduğunu, Ybarra ve Kimberly (2004) de internetin yoğun kullanımının siber mağduriyetin yordayıcısı olduğunu belirtmektedirler (Ybarra 2004; Topçu, Erdur-Baker \& Çapa-Aydın 2008; Baker 2010).

Araştırmada öğrencilerin kaçıncı sınıfta okudukları arasında siber zorbalık ölçeği puanı açısından istatistiksel olarak anlamlı fark bulunmaktadır. Buna göre siber zorbalık ölçeği sınıf değişkenine göre farklılık yaratmaktadır. Siber zorbalık ölçeği puanları açısından 10 ve 11 . sınıfta okuyan bireylerin lehine anlamlı bir fark vardır. Araştırmada sınıf düzeyi arttıkça siber mağduriyetin arttığını söylemek mümkündür.

Literatür araştırmaların da Burnukara'nın (2009) araştırması da siber zorbalığa maruz kalma oranlarının üst sınıflarda alt sınıflardan daha yüksek olduğu şeklindedir. Kowalski ve Limber'in (2007), Ybarra ve Kimberly'nin (2004) ve Campbell'in (2005) araştırma sonuçları da bu bulgumuzla örtüşür nitelikte olup siber mağduriyet puanlarının sınıf düzeyi arttıkça yükseldiği yönündedir (Ybarra 2004; Campbell 2005; Kowalski \& Limber 2007; Burnukara 2009).

Siber zorbalığın sınıf düzeyi ile ilişkisine bakıldığında, Burnukara'nın (2009), Özdemir ve Akar'ın (2011), siber zorbalığın sınıf düzeylerine göre farklılık göstermediği yönündeki araştırma sonuçları, bu bulgumuzla örtüşmektedir (Burnukara 2009; Özdemir \& Akar 2011).

Araştırmada sosyo-demografik değişken olarak ele alınan ebeveynlerin eğitim durumu ile siber zorbalık arasındaki en önemli ilişkilerden biri de annesi okur-yazar olmayan bireylerin lehine anlamlı bir fark vardır.

Araştırmada öğrencilerin babalarının eğitim düzeyleri arasında siber zorbalık ölçeği puanı açısından istatistiksel olarak anlamlı fark bulunmaktadır. Buna göre siber zorbalık ölçeği eğitim değişkenine göre farklılık yaratmaktadır. Siber zorbalık ölçeği puanları açısından babası üniversite mezunu olan bireylerin lehine anlamlı bir fark vardır. Düşük gelir seviyesine sahip 
ebeveynlere sahip çocukların kendilerine ait iletişim araçlarına sahip olma oranları da daha düşük olabilmektedir. Kendilerine ait bilgisayarı olmayan çocuklar internete erişimi internet kafelerden sağlayabilir. Araştırma sonuçlarından da görüldüğü gibi internete internet kafeden giren çocukların siber zorbalık davranışlarında bulunma olasılıkları diğer yerlerden erişim sağlayanlara göre daha fazladır.

Araştırmada öğrencilerin okul başarı düzeyleri arasında siber mağduriyet ölçeği puanı açısından istatistiksel olarak anlamlı fark bulunmaktadır. Buna göre siber mağduriyet ölçeği başarı değişkenine göre farklılık yaratmaktadır. Siber mağduriyet puanları açısından okul başarısı düşük olan bireylerin lehine anlamlı bir fark vardır. Gruplar arasındaki farklılıklar incelendiğinde, algılanan ders başarısı düşük ve çok düşük olan öğrenciler ile dersleri iyi olan öğrencilerin siber zorbalık puanları arasında dersleri iyi öğrenciler lehine anlamlı bir fark varken; algılanan ders başarısı düşük olan öğrenciler, ders başarısı iyi olan öğrencilere göre daha fazla siber mağdur olmaktadır. Agatson, Kowalski ve Limber'in (2007) araştırmalarına göre siber zorbalık davranışlarına maruz kalan öğrencilerde, okuldan soğuma, okuldan kaçma, okul başarısında düşüşler yaşama ve derse odaklanamama gibi durumların meydana geldiği görülmektedir. Aynı zamanda Hinduja ve Patchin (2009) de siber zorbalığa maruz kalan öğrencilerin okul başarılarında düşüş gözlemlendiğini vurgulamaktadır. Bu durum araştırma bulgularımızla örtüşmektedir.

Araştırmada bireylerin ne kadar süre internette girdikleri arasında siber zorbalık ölçeği puanı açısından istatistiksel olarak anlamlı fark bulunmaktadır. Buna göre siber zorbalık ölçeği internet süresine göre farklılık yaratmaktadır. Siber zorbalık ölçeği puanları açısından günlük 5 saat ve üzerinde internete giren bireylerin lehine anlamlı bir fark vardır.

Yapılmış literatür araştırmalarına bakıldığında, Hinduja ve Patchin (2008), interneti sık kullanan ve kullanmayan bireyleri karşılaştırmış ve mağdur olanların, zorbalığa hiçbir şekilde bulaşmamış olanlardan daha fazla internet kullandığını belirtmiştir. Başka bir çalışmada ise interneti kullanma durumuna göre zorbalığa bakılmış ve internet kullananların kullanmayanlardan daha fazla zorbalıkla karşılaştıkları görülmüştür (Hinduja \& Patchin 2008).

Siber zorbalık davranışları, bu davranışların sebep ve sonuçları, siber mağdurların yaşadığı sorunlar ve bu sorunlara yönelik çözüm önerileriyle ilgili okul yöneticileri, psikolojik danışman ve rehberlik uzmanları, öğretmen, öğrenci ve velilere yönelik konuyla ilgili bilgilendirici çalışmaların yapılmasının yararlı olacağı düşünülmektedir. Bu tür çalışmalar ile bu kitlenin siber zorbalık kavramıyla ilgili farkındalık düzeylerinin artırılması, öğrencilerin siber zorbalık davranışları ve mağduriyetlerinin önlenmesinde yararlı olabilir.

Siber zorbalık ve siber mağduriyet çok eskiye dayanmayan bir çalışma alanı olmakla birlikte bu konuda yapılan çalışmalara bakıldığında, çalışmaların büyük kısmının tanımlama, sınıflandırma ve yaygınlık düzeyine ilişkin olduğu görülmektedir. Elbette bu çalışmaların önemi azımsanamaz; ancak siber zorbalık ve siber mağduriyetin daha iyi anlaşılabilmesi için farklı değişkenlerle olan ilişkilerine de bakılması gerekmektedir. Ayrıca mevcut çalışmalar daha çok siber zorbalık konusu üzerinde durmakta; siber mağduriyet konusu ise zorbalığın sonucu olarak ele alınmaktadır. Bu bakımdan siber mağduriyet konusunda daha fazla çalışma yapılmasının, alana daha fazla katkı sunacağı düşünülmektedir.

$\mathrm{Bu}$ çalışma, katılımcıların ölçeklere verdikleri yanıtlarla sınırlıdır, elde edilen bulguların yorumlanmasında ve genellemesinde çalışmanın sinırlılıkları göz önünde bulundurulmalıdır. Araştırmada ergenlerin siber ortamdaki zorbalık deneyimleri kendini bildirim türü ölçeklerle ve tek oturumda ölçülmüştür. 


\section{KAYNAKÇA}

Agatston P.W., Kowalski R. \& Limber S. (2007). “Student’s Perspective on Cyber Bullying”. Journal of Adolescent Health 41/6 (2007) 59-60.

Arıcak O. T., Kınay H. \& Tanrıkulu T. (2012). “Siber Zorbalık Ölçeği'nin İlk Psikometrik Bulguları". Hasan Ali Yücel Ĕgitim Fakültesi Dergisi 17/1 (2012) 101-114.

Arıcak O. T. (2009). "Psychiatric Symptomatology As a Predictor of Cyberbullying Among University Students”. Eğitim Araştımaları-Eurasian Journal of Educational Research 34 (2009) 167-184.

Baker K. M. (2010). Florida Teacher Perceptions Concerning Internet Dangers For Students. Phd Thesis. University of Central Florida, Department of Educational Research, Orlando 2010.

Bayraktar S. (2012). Psikolojik Travma. İstanbul 2012.

Belsey B. (2007). “Cyberbullying: A Real And Growing Threat”. ATA Magazine 88/1 (2007) 14-27.

Beran T. \& Li Q. (2005). “Cyber Harassment: A Study of New Method For An Old Behavior”. Journal of Educational Computing Research 32/3 (2005) 265-277.

Burnukara P. (2009). Illk ve Orta Ergenlikte Geleneksel ve Sanal Akran Zorbalığına İlişkin Betimsel Bir İnceleme. Yayımlanmamış Yüksek Lisans Tezi. Hacettepe Üniversitesi, Sosyal Bilimler Enstitüsü, Ankara 2009.

Campbell M. A. (2005). “Cyber Bullying: An Old Problem in a New Guise?”. Australian Journal of Guidance and Counselling 15/1 (2005) 68-76.

Çivilidağ A. \& Cooper H. T. (2013). “Ergenlerde Siber Zorba ve Öfkenin İncelenmesi Üzerine Bir Araştırma: Niğde İli Örneği”. International Journal of Social Science 6/1 (2013) 497-511.

Erdur-Baker Ö. \& Kavşut F. (2007). "Cyber Bullying: A New Face Of Peer Bullying”. Eurasian Journal of Educational Research 27 (2007) 31-42.

Eroğlu Y. \& Peker A. (2011). "Aileden ve Arkadaştan Algılanan Sosyal Destek ve Siber Mağduriyet: Yapısal Eşitlik Modeliyle Bir İnceleme”. Akademik Bakış Dergisi 27 (2011) 1-20.

Freedman J. L., Sears D. O. \& Carlsmith J. M. (1998). Sosyal Psikoloji. Çev. Prof. Dr. Ali Dönmez. Ankara 1998.

Hinduja S. \& Patchin J. W. (2009). Bullying Beyond The Schoolyard: Preventing and Responding to Cyberbullying. California 2009.

Hinduja S. \& Patchin J. W. (2008). "Cyberbullying: An Exploratory Analysis of Factors Related to Offending and Victimization”. Deviant Behavior 29 (2008) 129-156.

Hinduja S. \& Patchin J. W. (2007). "Offline Consequences of Online Victimization: School Violence and Delinquency”. Journal of School Violence 6/3 (2007) 89-112.

Kowalski M. R. \& Limber S. P. (2007). "Electronic Bullying Among Middle School Students”. Journal of Adolescent Health 41/6 (2007) 22-30.

Li Q. (2006). "Cyberbullying in Schools: A Research of Gender Differences”. School Psychology International 27 (2006) 157-170.

Manap A. (2012). İlköğretim İkinci Kademe Öğrencileri ve Siber Zorballk: Samsun İli Örneği. Yayımlamamış Yüksek Lisans Tezi. Ondokuz Mayıs Üniversitesi, Eğitim Bilimleri Enstitüsü, Samsun 2012.

Özbay A. (2013). Ergenlerde Siber Zorbalık, Siber Mağduriyet, Aleksitimi ve Öfke Iffade Etme Biçimleri Arasındaki İlişki. Yayımlanmamış Yüksek Lisans Tezi. Fatih Üniversitesi, Sosyal Bilimler Enstitüsü, İstanbul 2013.

Özdemir M. \& Akar F. (2011). "Lise Öğrencilerinin Siber -Zorbalığa İlişkin Görüşlerinin Bazı Değişkenler Bakımından İncelenmesi”. Kuram ve Uygulamada Eğitim Yönetimi $17 / 4$ (2011) 605-626.

Özer A. K. (1994). "Sürekli Öfke (SL-Öfke) ve Öfke İfadesi Tarzı (Öfke-Tarz) Ölçekleri Ön Çalışması”. Türk Psikoloji Dergisi 9/31 (1994) 26-35.

Patchin J. W. \& Hinduja S. (2006). "Bullies Move Beyond The Schoolyard”. Youth Violence and Juvenile Justice 4/2 (2006) 148-169.

Sarak Ö. (2012). Lise Öğrencilerinde Siber Zorballk. Yayımlanmamış Yüksek Lisans Tezi. Haliç Üniversitesi, 
Sağlık Bilimleri Enstitüsü, İstanbul 2012.

Savaşır I. \& Şahin N. H. (1997). Bilişsel-Davranışçı Terapilerde Değerlendirme: Slk Kullanılan Ölçekler. Ankara1997.

Smith P., Mahdavi J., Carvalho M. \& Tippett N. (2006). "An Investigation Into Cyberbullying, its Forms, Awareness and Impact, and the Relationship Between Age and Gender in Cyberbullying”. A Report to the Anti-Bullying Alliance. Source: http://www.staffsscb.org.uk/Professionals/Key-Safeguarding/eSafety/Task-to-Finish-Group/Task-to-Finish-Group-Documentation/Cyber-Bullying---FinalReport.pdf

Soydaş D. K. (2011). Ergenlerde Ebeveyn İzlemesi, Sanal Zorbalı ve Yaşam Doyumu Arasındaki İlişkilerin Cinsiyete Göre İncelenmesi. Yayımlanmamış Yüksek Lisans Tezi. Hacettepe Üniversitesi Sosyal Bilimler Enstitüsü, Ankara 2011.

Şahin N. H. \& Şahin N. (1992). "Adolescent Guilt, Shame, and Depression in Relation to Sociotrophy and Autonomy". Paper presented at the World Congress of Cognitive Therapy, Toronto, Canada June, 17-21.

Şahin N. H. \& Durak A. (1995). "Stresle Başaçıkma Tarzları Ölçeği: Üniversite Öğrencileri İçin Uyarlanması". Türk Psikoloji Dergisi 10/34 (1995) 56-73.

Şahin M., Sarı S. V., Özer Ö. \& Er S. H. (2010). "Lise Öğrencilerinin Siber Zorba Davranışlarında Bulunma ve Maruz Kalma Durumlarına İlişkin Görüssleri”. SDÜ Fen Edebiyat Fakültesi Sosyal Bilimler Dergisi 21 (2010) 257-270.

Tanrıkulu T., Arıcak O. T. \& Kınay H. (2011).”Siber Zorbalık Ölçeğinin İlk Psikometrik Bulguları”. XI. Ulusal Psikolojik Danışma ve Rehberlik Kongresi Bildiri Özetleri Kitabı. İzmir (2011) 340-341.

Topçu Ç., Erdur-Baker Ö. \& Çapa-Aydin Y. (2008). "Examination of Cyberbullying Experiences among Turkish Students from Different School Types”. CyberPsychology \& Behavior 11/6 (2008) 643-648.

Walker H. M. (2010). "Relational Aggression in Schools: Implications for Future Research on Screening Intervention and Prevention”. School Psychology Review 39/4 (2010) 594-600.

Yaman E., Eroğlu Y. \& Peker A. (2011). Başaçıma Stratejileriyle Okul Zorbalığı ve Siber Zorbalık. İstanbul 2011.

Ybarra M. L. (2004). "Linkages Between Depressive Symptomatology and Internet Harassment among Young Regular Internet Users”. CyberPsychology \& Behavior 7/2 (2004) 247-257.

Ybarra M. L. \& Kimberly J. M. (2004).”Youth Engaging in Online Harassment, Internet Use and Personal Characteristics". Association for Professionals in Social Services Journal for Adolescents 27/3 (2004) 319-336. 